\title{
Discussion on the Training Mode of School Enterprise Coeducation in the Specialty of Mechanical Manufacturing and Automation
}

\author{
Lidan Fan ${ }^{1, a^{*}}$, Youquan Chen ${ }^{2, b}$, Feng Yang ${ }^{1, c}$ and Zhuojuan Yang ${ }^{1, d}$ \\ ${ }^{1}$ College of Mechanical Engineering Jilin Teachers Institute of Engineering \& Technology Changchun, \\ China \\ ${ }^{2}$ Department of Mechanical Engineering Changchun Institute of Engineering Technology Changchun, \\ China \\ âFanlidan111@163.com, ㅁQuan3168@sina.com, yangfeng@163.com
}

Keywords: School enterprise coeducation; Work study combination; Science and engineering; Double teacher

\begin{abstract}
This paper to explore the necessity of school enterprise cooperation to foster talents, and according to the characteristics of mechanical manufacturing and automation specialty, puts forward machinery manufacturing and automation professional school enterprise education professionals training implementation of the specific content, closely rely on industries and enterprises, the employment oriented to establish course system, according to the job needs to reform the curriculum contents, to build high quality teaching materials and build both internal and external training base, to realize the conditions of factory training, teachers double teacher, teaching enterprise situation, teaching content of the project of Enterprise Co education of talent cultivation mode.
\end{abstract}

\section{Introduction}

School enterprise cooperation, the implementation of the talent training mode of combination of work and study, is the characteristics and advantages of Higher Vocational and technical education, is one of the most effective education mode of training highly skilled talents. School enterprise co-education is the deep integration of the enterprise, which is a higher level of ordinary school enterprise cooperation. That is in social education and training qualified talents with high skill this goal, schools and enterprises to carry out the depth of cooperation, jointly carry out production and the process of teaching, students' theoretical study and practical operation and training together, in order to improve the quality of the quality of education and the future of workers, and enhance the possibility of two-way choice between enterprises and graduates, and ultimately provide high-quality talents for the economic and social development. Its basic connotation is the combination of production and learning, mutual participation, professional practice. The purpose is to enhance the vitality of running a school, and to improve the students' comprehensive quality, in order to meet the demand of the market economy.

To ability based simulation training project and enterprise's actual production projects there are still large gaps, though to ability based simulation training project and enterprise's actual production projects there are still large gaps, although the use of the project teaching method, students to complete a project training from the surface. However, once asked the students to complete the task of a comprehensive, or required to complete the task by the standards of the enterprise processing, students tend to be helpless, incompetent enterprises work requirements, unable to realize zero distance employment. Therefore, the school must be introduced into the actual production situation of enterprises, so that students in the actual production of master skills. Machinery manufacturing and automation specialty is the practical very strong professional, students in addition to master the theoretical knowledge and basic skills, should also through some practical production of enterprises, in order to grasp the production process and processing technology. In addition, due to mechanical manufacturing materials, tools and other costs are very expensive, non-teaching of simulated training 
mode of the product cost is very high school should be more to strengthen cooperation with their counterparts in business, with the strength of enterprises to enhance the practical ability of students.

Automation received financial support from central government to improve the professional service ability of special construction projects, according to the needs of mechanical manufacturing and automation professional development, in order to improve the ability of the professional service to the community and regional economic, improve professional services "hardware" and "software" conditions, the college take school enterprise cooperation education professionals training mode, by school teachers and enterprise technical staff composed of teaching and production team, with "school plant one, teach simultaneously" principle, in accordance with the conditions of factory training, teachers double division of, teach in enterprise and project teaching content settings, college enterprise education professionals.

\section{The Implementation of the Training Mode of School Enterprise Co Education of Mechanical Manufacturing and Automation Specialty.}

School Enterprise Cooperation, the Establishment of the Curriculum System Based on the Working Process, Highlighting the Concept of Professional Curriculum Design. In the course of developing the course system, we adopt the course system of the combination of school and enterprise. In the process of construction, we introduce enterprise industry experts and our teaching experts together to discuss, research, development and production of the actual course. Mechanical manufacturing and automation professional should be combined with the needs of the professional development of mechanical manufacturing jobs, and gradually establish a "professional position ability to work as the direction of progressive" professional curriculum system. Development process using the four stage of progressive development process, first of all through professional research formation research report, then the vocational post ability demand obtained according to research reports, according to experts seminar, form in the field of curriculum planning, finally in the field of curriculum planning as the basis, after several teaching seminars, and ultimately the formation of professional curriculum system. In the field of learning planning, we according to the specific task of professional positions, and summed up the typical task. According to the ability of the work process analysis, obtains the professional ability, and the professional ability of action analysis, the same professional ability to induce the formation of specific learning areas.

In the process of curriculum development system, course construction group and Panzhihua Iron and steel company, Panzhihua Iron and steel automobile repair factory etc. metallurgical machinery manufacturing enterprises to carry out in-depth cooperation, firmly grasp the students' vocational ability training as the main line, analysis of the metallurgical machinery and equipment manufacturing related jobs working process and determine the course of the corresponding tasks and the ability to target.

Machinery manufacturing and automation specialty course system is to work ability progressive training principle, basic design ability, comprehensive use of core capability and professional technical ability course module, tasks and professional theory knowledge integration, the comprehensive quality of professional job culture into the teaching, stressed on the working process of knowledge learning, cultivate students' comprehensive professional ability.

The Introduction of the Industry Enterprise Technical Experts, In-depth Development of Teaching Projects, Integration of Teaching Content. We take "project oriented and task driven teaching model, but a good teaching model need specific programs to support, only the depth of the project teaching development, fit the actual production, some real production tasks into the teaching and the theoretical knowledge and practical skills training organically, integration, in order to essentially reflected the combined" Teaching mode. Teaching project as the carrier of teaching content, can "carry" professional knowledge and professional ability, and the integration of the two together, is the key to the development of "science and practice" teaching project. While standing in combined application of a frontier is the industry enterprise technology experts, so in the process of teaching 
development project must introduced to the industry enterprise technology experts, in order to achieve the depth of the development of the project teaching and fusion of science and teaching content. Such as in machinery manufacturing process and implementation of the curriculum development and construction, thanks to the industry and business experts to participate in, we according to metallurgy mechanical parts shape and manufacturing characteristics, summed up parts manufacturing kinds of five typical learning project, namely and shaft manufacturing projects, gear manufacturing project, a box rack body manufacturing project, bell valve manufacturing projects, metallurgical machinery equipment installation project, based on knowledge module and - knowledge preparation and practice application module - "comprehensive design" constitute the overall structure of the teaching project. The main learning projects are selected from five to three enterprises, through the transformation of the typical parts of the teaching of metallurgy as the carrier. All sources of project teaching in metallurgy manufacturing enterprise production project, select focus on typical, coverage, authenticity, focusing on support for the realization of teaching goal, after careful selection and appropriate modifications to form suitable for students learning tasks.

The Introduction of the Industry Enterprise Technical Experts, the Construction of the "Science and Technology in one" of the Structure of the Teaching Materials. Higher vocational education is a don't in the subject, the research and engineering of ordinary higher education, training skill type, application type talents is the basic connotation of the vocational education personnel training target, vocational education is directly to the local or industry economic development services, training objectives should stand out the characteristics of professional, industry and region .Technical experts of the industry enterprises stood at the forefront of technology application, the application of professional knowledge and skills in the professional post has the right to speak, from the perspective of professional application of textbook development put forward useful suggestions and provide valuable teaching project, especially in practice and teaching program development on, can take advantage of industry technical experts rich practical experience to provide guidance on practice teaching project settings. In the textbook writing introduced industry technical experts join can enable materials development more in line with the profession and practice, to ensure that the cultivation of students' practical ability, reflect the skill type, application type talents training requirements.

By introducing the industry enterprise technology experts involved in the preparation, we can grasp the material of writing direction, fully embodies the characteristics of occupational, more from post ability demand of the angle of sustainable development and to examine the teaching materials for vocational education, realize from the discipline standard to students professional ability standard shift. Such as in "mechanical manufacturing technology and implementation of teaching material construction, we use school enterprise combination, introduced metallurgical machinery manufacturing enterprises of senior engineers and senior technicians as a one person, and our hospital teaching experts and teachers together to jointly develop the construction based on" theory and practice combined structure of teaching material. In the construction of seize students professional ability training as the main line, analysis of the metallurgical machinery equipment manufacturing related jobs, to determine the course of the corresponding tasks and the ability to target, with typical metallurgical machinery parts manufacturing projects as the carrier, developed based on the working process of high-quality materials.

School Enterprise Cooperation to Build the Campus Training Room and off Campus Training Base. The construction of experimental training room from planning and design to the construction of the implementation, should be introduced into the area of influence of industry enterprises to participate in the construction, provide valuable guidance in order to achieve the training conditions of the factory. In the construction process, college teachers in-depth Panzhihua Iron and steel company, Gangcheng Enterprise Corporation subordinate machinery factory and other industries and enterprises for production process, equipment and technology research, fully listen to the enterprise technology expert advice, according to the needs of Panzhihua Iron and steel company, Gangcheng Enterprise a total of division and other units, combined with the equipment conditions in the plant, with the Panzhihua Iron and steel company, Gangcheng Enterprise Company production 
technology, equipment and technology to match the campus training base was established. The advantage of college education of enterprise, relying on the resource of Panzhihua, Establish the mechanism of school enterprise cooperation. Enterprises participate in guiding the construction of the experimental training room, design concept from the enterprise; equipment and technology refer to the enterprise, layout and follow the enterprise, to achieve the training environment factory.

Function of Outside Practice Base. Pay attention to and strengthen the construction of off campus training base, to make a clear definition of campus training base function, realize the function of compound, not only to meet the basic function of students' practice, but also have the function of outside classroom. Students in the production environment of the training of the training to get exercise, improve the professional skills and quality. After the internship let the students grasp the competence of enterprise specific jobs. And extracurricular practice base can also be as a school classroom, full-time teachers in the school can be in the enterprise outside the classroom teaching, the basic realization of the production scene and the scene of teaching effective docking, to ensure that students in the real work environment and real position learning, combination of production and study the real reality.

To Enterprise as a Platform to Foster the "Double Teacher" Teacher. The level of teachers often determines the level of development of a professional. Most teachers in our hospital machinery manufacturing and automation specialty, with the professional solid theoretical knowledge and rich experience in teaching, but most of the teachers lack professional engineering practice, professional work ability needs to be improved, cannot meet the higher professional services capabilities of teachers of double teacher quality requirements. In order to enhance" The double teacher type" teachers training should be based on the platform of enterprise, through the arrangement of full-time teachers factory hangs duty to take exercise, for teachers to create a further production of the first line of exercise, learning platform, thus to improve the teacher's professional teaching ability. As the enterprise, for teachers to provide for training, mainly through the teachers and technical personnel of enterprises together to complete the design, development and production of manufacturing project, so the teachers familiar with enterprise production process and operation process, understand the latest information technology, improve practical skills, which is an effective way to speed up the cultivation of teachers of "double teacher type".

Should be changed in the past, the theory divorced from practice "mode and educational idea, according to corporate jobs on the professional ability of the actual needs of the formulated teaching plan and syllabus, writing training courses and teaching materials, both to ensure the quality of personnel training in school and on the existing school management and teaching methods to promote the role. The training of the graduates of the two sides together, the training of graduates job adaptability and practical ability, strong employment competitiveness, can achieve the social, business, school satisfaction of the results of the three party.

\section{References}

[1] Yang Yue. Investigation and analysis of the situation of learning and thinking of Higher Vocational College Students [J]. mechanical vocational education, 2003, (7).

[2] Xu Chang. Higher vocational college students to study the psychological status of [J]. education and professional.2005, (17).

[3] The of AutoCAD. Gaolian stone inquiry teaching learning [J]. Journal of Suzhou Institute of Education $(2006,2)$.

[4] Cai Keyong.21 century Chinese education to [M]. Guangdong higher education press, 2004

[5] Jiaquan. The enterprise team spirit [J]. Shanghai Trade Union College Journal, 2010, (5). 